11. Manyukov, VN, AA. Stadnikov, O M. Trubina, AD. Strekalovskaya Methods of research in biology and medicine. Orenburg state un-t. Orenburg: OSU, $2013 .-192 p$.

12. Rossi A, Mammucari C, Argentini C, Reggiani C, Schiaffino S. Two novel/ancient myosins in mammalian skeletal muscles: MYH14/7b and MYH15 are expressed in extraocular muscles and muscle spindles. The Journal of Physiology. 2010;588(2): 35364. https://doi.org/10.1113/jphysiol.2009.181008

13. Sakuma K, Wataru A, Yamaguchi A. The Intriguing Regulators of Muscle Mass in Sarcopenia and Muscular Dystrophy. Frontiers in Aging Neuroscience. 2014,29(6): 234 - 239. https://doi.org/10.3389 /fnagi. 2014.00230

14. Schiaffino S, Reggiani C. Fiber Types in Mammalian Skeletal Muscles. Physiological Reviews. 2011,91(4):1447-1531. https://doi.org/10.1152/physrev.00031.2010

15. Soldatov AA. The Diffusion Capacity of the Hematoparenchymal Barrier in Mammalian and Marine Fish Skeletal Muscles. Evolutionary Biochemistry and Physiology. 2018,54(1): 43-49. https://doi.org/10.1134/s0022093018010052

Стаття надійшла 22.05.2020 p.

DOI 10.26724/2079-8334-2021-2-76-232-238

UDC 616.379-008.64:616.71-091-092.9

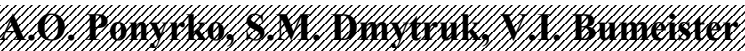

SWM

\title{
BIOMECHANICAL PROPERTIES AND MACROELEMENT ELEMENT COMPOSITION OF LONG TUBULAR BONE OF RATS UNDER EXPERIMENTAL HYPERGLYCAEMIA
}

e-mail: ponyrkoalina123@gmail.com

The pathomorphological basis for the development of diabetic disorders in various bones is a relevant subject of modern experimental research on the modeling of diabetes-associated destructive processes in the skeletal system. They are characterized by reduced bone density, which leads to an increased risk of fractures. Bone strength mainly depends on the interaction and concentration of chemical elements such as $\mathrm{Ca}, \mathrm{P}, \mathrm{Mg}$, and $\mathrm{K}$. Therefore, the purpose of our study was to determine the interdependence of changes in biomechanical parameters depending on the concentration of chemical elements in long tubular bones of rats under chronic hyperglycemia. The study was performed on 72 adult white laboratory rats lasting 180 days. It was found that starting from 30 days of uncontrolled chronic hyperglycemia, the bone mineral density in rats of the experimental group gradually decreased in comparison with the dynamics of the corresponding indexs in animals of the control group. These changes were accompanied by pronounced demineralization of both bones, as evidenced by significant losses of macronutrients $(\mathrm{Ca}, \mathrm{P}$, $\mathrm{Mg}$ and $\mathrm{K}$ ). As a result, in chronic hyperglycemia gradually formed a complex violation of the structure and biomechanical properties of long tubular bones, which is a pathomorphological basis in the corresponding loci of the skeletal system.

Key words: rats, hyperglycemia, tubular bones, bone mineral density, macronutrient bone composition.

\section{А.О. Понирко, С.М. Дмитрук, В.І. Бумейстер \\ БІОМЕХАНІЧНІ ВЛАСТИВОСТІ ТА МАКРОЕЛЕМЕНТНИЙ СКЛАД ДОВГИХ ТРУБЧАСТИХ КІСТОК ЩУРІВ ЗА УМОВ ЕКСПЕРИМЕНТАЛЬНОӤ ГІПЕРГЛІКЕМІї}

Патоморфологічне підгрунтя розвитку діабетичних порушень у різних кістках є актуальним предметом сучасних експериментальних досліджень 3 моделювання діабет-асоційованих деструктивних процесів у системі скелету. Для них характерна знижена щільність кісток, що призводить до підвищення ризику переломів. Міцність кісток переважно залежить від взаємодії та концентрації хімічних елементів, таких як $\mathrm{Ca}, \mathrm{P}, \mathrm{Mg}$ та К. Тому метою нашого дослідження було визначення взаємозалежності зміни біомеханічних показників в залежності від рівня концентрації хімічних елементів у довгих трубчастих кістках щурів за умов хронічної гіперглікемії. Дослідження було проведено на 72 статевозрілих білих лабораторних щурах тривалістю 180 діб. Встановлено, що, починаючи з 30 доби неконтрольованої хронічної гіперглікемії мінеральна щільність кісток щурів експериментальної групи поступово зменшувалася у порівнянні 3 динамікою відповідних показників у тварин контрольної групи. Зазначені зміни супроводжвались вираженою демінералізацією обох кісток, про що свідчать значні втрати макроелементів: Сa, P, Mg та К. У підсумку, в умовах хронічної гіперглікемії поступово формується комплексне порушення структури та біомеханічних властивостей довгих трубчастих кісток, яке являє собою патоморфологічну основу розвитку діабетичних змін у відповідних локусах системи скелету.

Ключові слова: щури, гіперглікемія, трубчасті кістки, мінеральна щільність кістки, макроелементний склад кісток.

The study is a fragment of the research project "Morphofunctional aspects of homeostasis", state registration No. 0118 U006611.

Hyperglycemia is a pathognomonic symptom of diabetes mellitus (DM) - a disease that occurs due to insulin deficiency or insulin resistance and is accompanied by metabolic disorders and the development of pathological changes in bone tissue, resulting in an increased risk of fractures and inhibition of healing $[4,5,12]$.

Morphological basis and pathological mechanisms of relationship between diabetes and skeletal health is the subject of debate for a long time, since it is known that glucose metabolism is closely associated with bone metabolism through regulated insulin secretion by the pancreas and adipose tissue $[9,14]$. 
Bone pathology is considered a comorbid condition in diabetes mellitus, the mechanism of development of which is associated with hyperglycemia and accumulation of end products of collagen glycation in the bone matrix, hypoinsulinemia (type 1 diabetes) or insulin resistance (type 2 diabetes mellitus), autoimmune inflammation. The negative impact on bone tissue of some drugs used to control hyperglycemia exacerbates the problem $[6,7,14]$.

Some issues of pathomorphological and pathophysiological mechanisms of the development of diabetic disorders in bone tissue to this day remain indeterminate.

First, it should be noted the need for a deeper argumentation of hypotheses about the violation of the process of bone mineralization in diabetes $[8,11]$. Given the large number of results of clinical and experimental studies on the study of diabetic disorders of the vertebrae and femurs, which underlie the corresponding risk of fractures, it should be noted insufficient study of pathological changes in other loci of the skeleton and areas of individual bones, including in age and gender aspects, which causes a certain problem of adequate justification of the mechanisms of osteopathy in diabetes $[2,4,12,13]$.

Therefore, further study of (diabetes-associated) qualitative and quantitative changes in bone structure is relevant, given the need to refine them and improve the evidence base to improve the effectiveness of appropriate preventive and curative measures.

The purpose of the study was to determine changes in the biomechanical properties and macronutrient composition of the long tubular bones of adult rats under conditions of chronic hyperglycemia.

Materials and methods. The study was performed on 72 mature white nonlinear rats weighing 180-200 g (Vivarium of Sumy State University's Medical Institute). Throughout the experiment, rats kept in vivarium on a standard diet and drinking regime. The experiment was performed in accordance with the requirements of the European Convention for the Protection of Vertebrate Animals Used for Experimental and Other Scientific Purposes (Strasbourg, 1986), the General Ethical Principles for Animal Experiments, adopted by the First National Congress on Bioethics (Kyiv, 2001), Helsinki Declaration of the General Assembly of the World Medical Association (Helsinki, 2000).

Experimental animals were divided into two groups: experimental $(n=36)$ and control $(n=36)$. Rats of the experimental group after 10-hour fasting were introduced into a state of chronic hyperglycemia by a single intraperitoneal injection of a solution of Alloxan-Dihydrate (LaChema, Czech Republic) at a dose of $150 \mathrm{mg} / \mathrm{kg}$ body weight in $0.9 \%$ sodium chloride solution. Rats were injected intraperitoneally controls similar about volume of $0.9 \%$ sodium chloride solution.

The experimental group, according to the duration of chronic hyperglycemia, was divided into 6 subgroups (for 6 animals in each subgroup): 1 - rats with a period of chronic hyperglycemia 30 days, 2 60 days, 3 - 90 days, subgroup, $4-120$ days, 5 - 150 days, and $6-180$ days.

The level of glucose in the blood of rats was determined by glucose oxidase method using diagnostic kits LLC SPE "Philisit-Diagnostics" (Ukraine). Urine glucose levels were determined by the express method using CITOLAB G test strips (Pharmasco, Ukraine). The concentration of HbA1c in whole blood was determined on a biochemical analyzer GBG ChemWell 2910 (Awareness Technology, USA) using diagnostic kits manufactured by SPINREACT (Spain).

The state of hyperglycemia was ascertained under the conditions of development of the corresponding symptom complex in animals: polydipsia, polyuria, and increase in blood glucose concentration $(>7.0 \mathrm{mmol} / \mathrm{L})$, glucosuria, and increase in glycated hemoglobin concentration $(>6.1 \%)$. Animals were sacrificed every 30 days of observation by decapitation under light thiopental-sodium anesthesia. Both femurs and humerus were removed for the study.

Studies of the biomechanical properties of bones were performed no later than one day after their removal (bones were stored in saline at a temperature of $0^{\circ} \mathrm{C}$ to $-1^{\circ} \mathrm{C}$. Evaluated the following indexs cross - sectional area $\left(\mathrm{S}, \mathrm{mm}^{2}\right)$, compression load $(\sigma, \mathrm{H})$, compressive stress $(\mathrm{M}, \mathrm{MPa})$ the tests were performed on an explosive machine IR - 5074 - 3 with a pendulum force meter and a manual horizontal drive. Photographs of bone fractures were obtained on a microscope MPB - 2 using a digital camera Cyber - shot $6.0 \mathrm{mp}$. Determination of the cross-sectional area was used with a caliper ShTs-1-150-0.05 GOST $166-$ 89 Determination of the chemical composition of tubular bones was performed on an atomic absorption spectrophotometer C -115 . M1.

Statistical analysis of the results of studies performed using Statistical v. 10 ("Stat Soft Inc.", USA). A descriptive analysis of each sample was performed based on Mean (M) and Standard Deviation (SD). The difference was considered significant at $\mathrm{p}<0.05$.

Results of the study and their discussion. On the 2nd day of the experiment, the animals of the experimental group had polydipsia and polyuria, the mean serum glucose concentration was by 3.5 times higher than that of the control group animals. 
The mean HbAlc concentration was by 1.2 times higher (but was within normal limit), the mean level of glucosuria was $55.12 \pm 2.43 \mathrm{mmol} / \mathrm{L}$. Subsequently, up to 180 days of the experiment, the animals of the experimental group maintained stable hyperglycemia, glucosuria and there was a gradual increase in the concentration of $\mathrm{HbAl} \mathrm{c}$, which is a marker of the magnitude and duration of hyperglycemia.

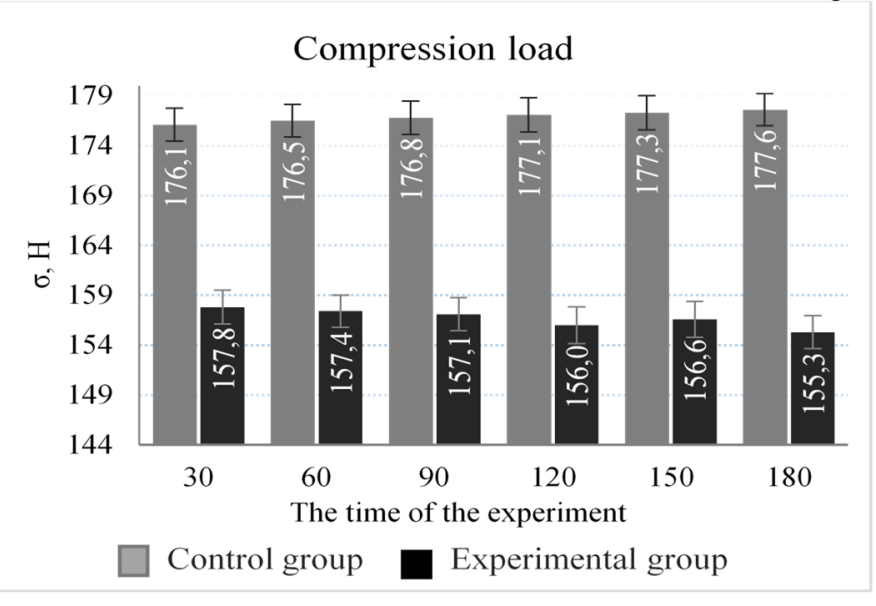

a

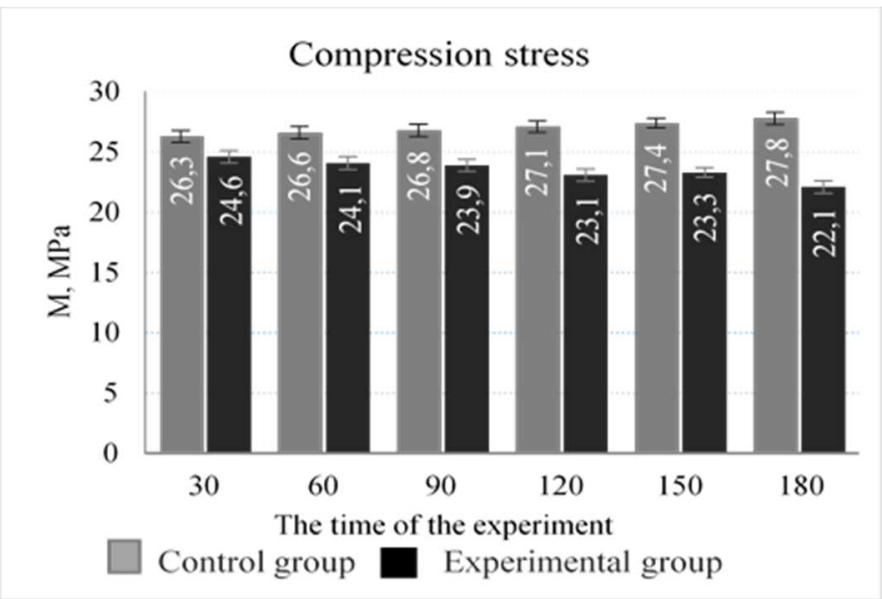

b

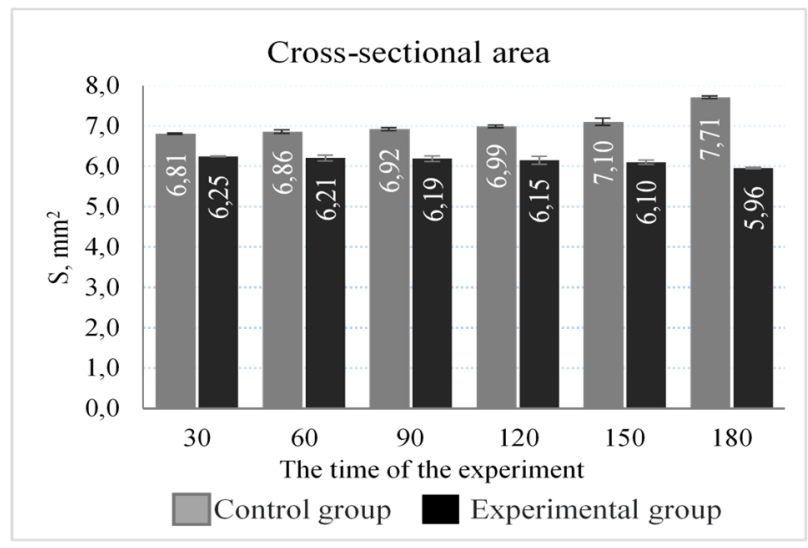

c

Fig. 1. The main biomechanical parameters of the femur of rats in the dynamics of the experiment

Note: all settings when paired comparison of control and experimental subgroups $(\mathrm{p}<0.05)$

In general, the indices of carbohydrate metabolism in the rats of the experimental group indicated the presence of persistent uncontrolled hyperglycemia, and their dynamics during the experiment reflected the features of compensatory-adaptive changes in animals under these conditions.

The biomechanical properties of the femur of rats in the dynamics of the experiment changed as follows. From 30 days to 180 days of chronic hyperglycemia, the strength of the femur, according to the compression load, in the animals of the experimental group decreased by $1.6 \%$ (fig. 1a). At the same time, in animals of the control group, the mean value of this index increased by $0.9 \%$ throughout the experiment. The mean value of the load on the compression of the femur in animals of the experimental group on day 30 was by $11.6 \%$ lower than in animals of the control group $157.8 \pm 1.69 \mathrm{~N}$ and $176.1 \pm 1.65 \mathrm{~N}$, respectively, $\mathrm{p}<0.001$. For 180 days, the difference between the mean values of the load on the compression of the femur in animals of the experimental and control groups was $12.6 \%$ $(155.3 \pm 1.65 \mathrm{~N}$ and $177.6 \pm 1.60 \mathrm{~N}$, respectively, $\mathrm{p}<0.001)$.

The mean index of stress during compression of the femur in the animals of the experimental group also decreased significantly during the entire period of the experiment by $10.2 \%$ (fig. 1b). Instead, in the animals of the control group in the dynamics of the experiment, its mean value increased by $5.7 \%$. The mean values of stress during compression of the femur in the animals of the experimental group were significantly lower than in the animals of the control group, starting from 30 days of observation $(24.6 \pm 0.51 \mathrm{MPa}$

and $26.3 \pm 0.49 \mathrm{MPa}$, respectively, $\mathrm{p}<0.001)$ and until the end of the experiment $(22.1 \pm 0.52 \mathrm{MPa}$ and $27.8 \pm 0.51 \mathrm{MPa}$, respectively, $\mathrm{p}<0.001)$.

In the animals of the experimental group during the experiment there was a decrease in the crosssectional area of the femur by $4.6 \%$, while in the animals of the control group this figure increased by $13.2 \%$ (fig. 1c). The difference in the mean values of the cross - sectional area of the femur in animals of the experimental and control groups was: at 30 days $-8.2 \%\left(6.25 \pm 0.01 \mathrm{~mm}^{2}\right.$ and $6.81 \pm 0.02$ 
$\mathrm{mm}^{2}$ respectively, $\left.\mathrm{p}=0.012\right), 180$ days $-14.9 \%\left(6.56 \pm 0.02 \mathrm{~mm}^{2}\right.$ and $0.03 \pm 7.71 \mathrm{~mm}^{2}$ respectively, $\mathrm{p}=0.007)$.

The biomechanical properties of the rat humerus in the dynamics of the experiment changed in a similar way to the described changes in the properties of the femur. From 30 days to 180 days of observation, the mean value of the load on the compression of the humerus in the animals of the experimental group decreased by $2.7 \%$ (fig. 2a). In animals of the control group, the mean value of this index, on the contrary, increased by $1.7 \%$.

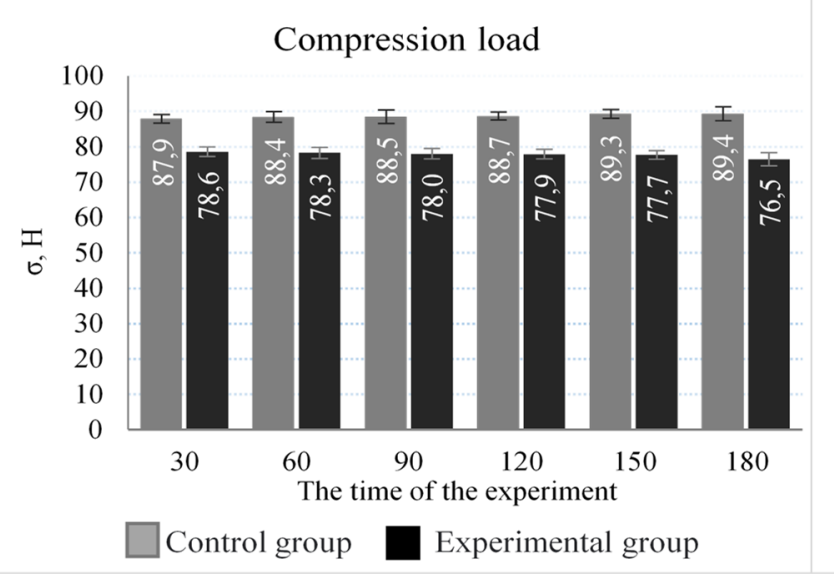

a

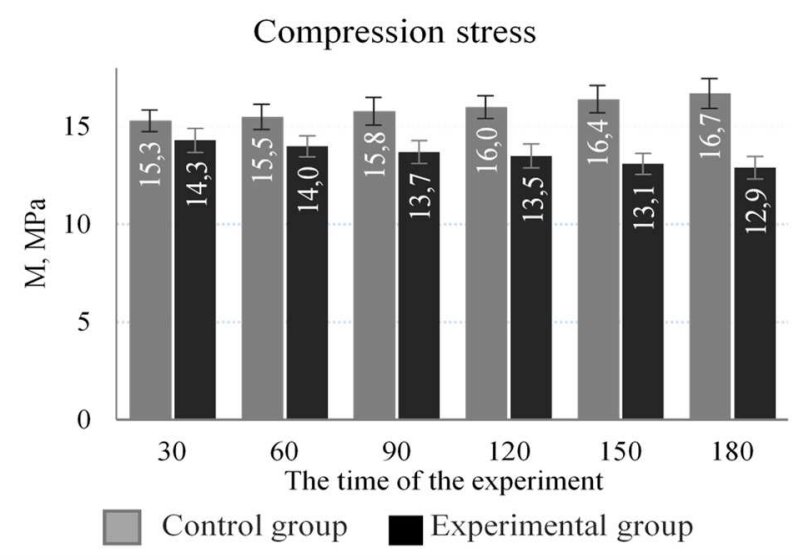

b

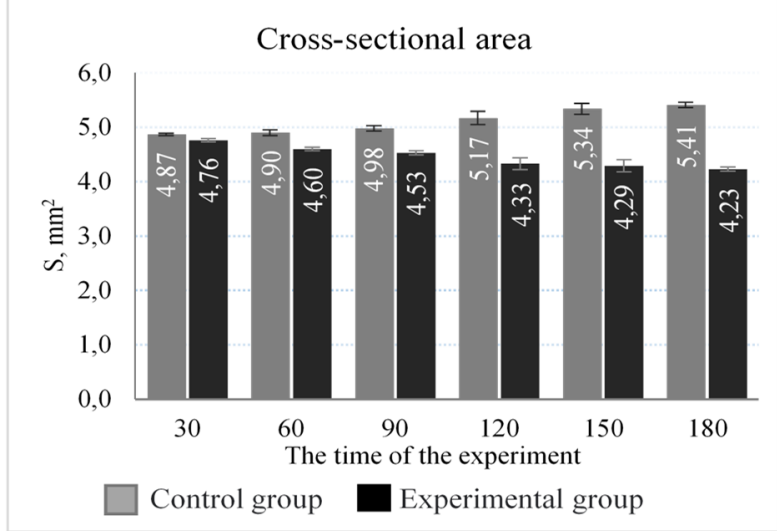

$\mathrm{c}$

Fig. 2. The main biomechanical parameters of the humerus of rats in the dynamics of the experiment

Note: all settings when paired comparison of control and experimental subgroups $(\mathrm{p}<0.05)$
The mean value of the burden on the humerus compression in animals of the experimental group on the 30th day of observation was $10.6 \%$ lower than in animals of the control group $-78.6 \pm 1.35 \mathrm{~N}$ and $87.9 \pm 1.18 \mathrm{~N}$, respectively, $\mathrm{p}=0.001$. On day 180 , the difference between the mean values of the load on the compression of the humerus in animals of the experimental and control groups was $14.4 \%(76.5 \pm 1.87 \mathrm{~N}$ and $89.4 \pm 1.97 \mathrm{~N}$, respectively, $\mathrm{p}<0.001)$.

The mean index of stress during compression of the humerus in the animals of the experimental group also significantly decreased from 30 to 180 days of the experiment by $9.8 \%$ (fig. 2 b). In the animals of the control group in the dynamics of the experiment, the mean value of stress during compression of the humerus increased by $9.2 \%$. The mean values of the stress during compression of the humerus in the animals of the experimental group were significantly lower than in the animals of the control group, starting from 30 days of observation $(14.3 \pm 0.61 \mathrm{MPa}$ and $15.3 \pm 0.55 \mathrm{MPa}$, respectively, $\mathrm{p}=0.023$ ) and up to 180 days of the experiment $(12.9 \pm 0.57 \mathrm{MPa}$ and $16.7 \pm 0.76 \mathrm{MPa}$, respectively, $\mathrm{p}<0.001)$.

In animals of the experimental group from 30 to 180 days of the experiment there was a decrease in the value of the crosssectional area of the humerus by $12.5 \%$, while in animals of the control group this index increased by $11.08 \%$ (fig. 2c). The difference in the mean values of the cross sectional area of the humerus in animals of the experimental and control groups was: for 30 days - $2.3 \%\left(4.76 \pm 0.03 \mathrm{~mm}^{2}\right.$ and $4.87 \pm 0.02 \mathrm{~mm}^{2}$ respectively, $\left.\mathrm{p}=0.026\right), 180$ days $-21.8 \%\left(4.23 \pm 0.04 \mathrm{~mm}^{2}\right.$ and $5.41 \pm 0.05 \mathrm{~mm}^{2}$, respectively, $\mathrm{p}=0.019$ ).

From the 30th day until the end of the experiment, the mean $\mathrm{Ca}$ content in the femurs of the animals of the experimental group decreased by $42.9 \%$, while in the animals of the control group, this figure increased by $28.7 \%$ (fig. 3a). For 180 days

of uncontrolled hyperglycemia, the difference in the mean $\mathrm{Ca}$ content in the femurs of the experimental and control animals was $61.8 \%(1.20 \pm 0.21 \mathrm{mg} / \mathrm{g}$ and $3.14 \pm 0.22 \mathrm{Mg} / \mathrm{g}$, respectively, $\mathrm{p}<0.001)$. 


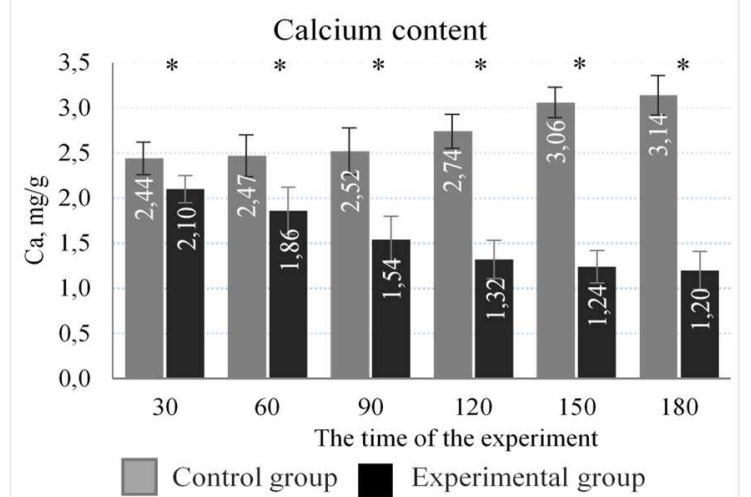

a

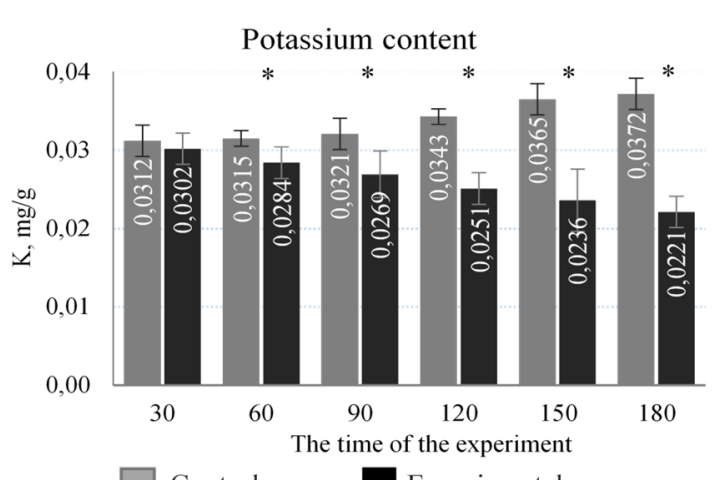

Control group Experimental group

d

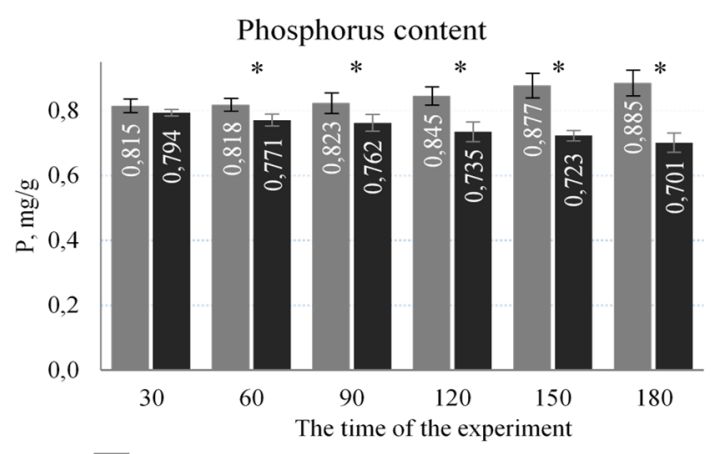

Control group $\square$ Experimental group b

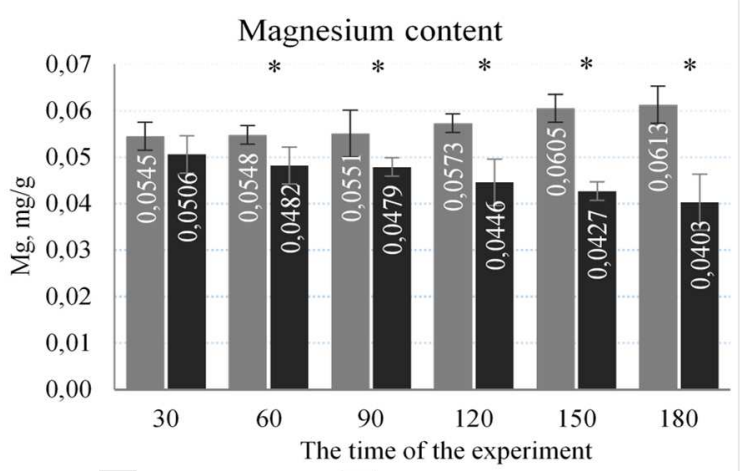

Control group $\square$ Experimental group

c

Fig. 3. The main indexs of the macronutrient composition of the femur of rats in the dynamics of the experiment.

Note: for all parameters in pairwise comparisons of the corresponding control and experimental subgroups $(\mathrm{p}<0.05)$.

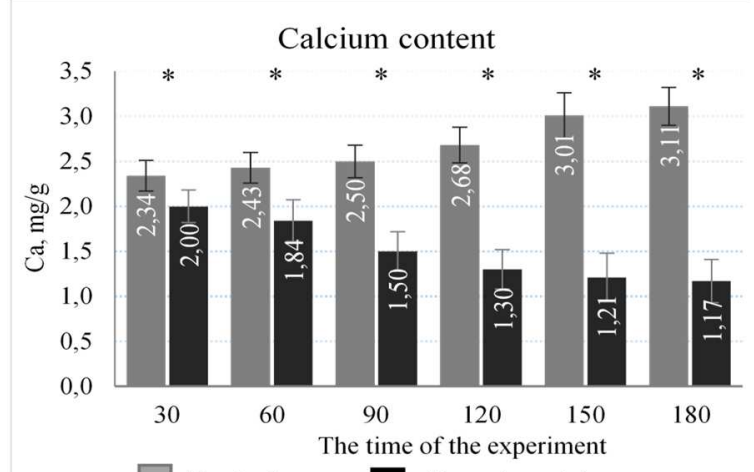

Control group $\square$ Experimental group

a

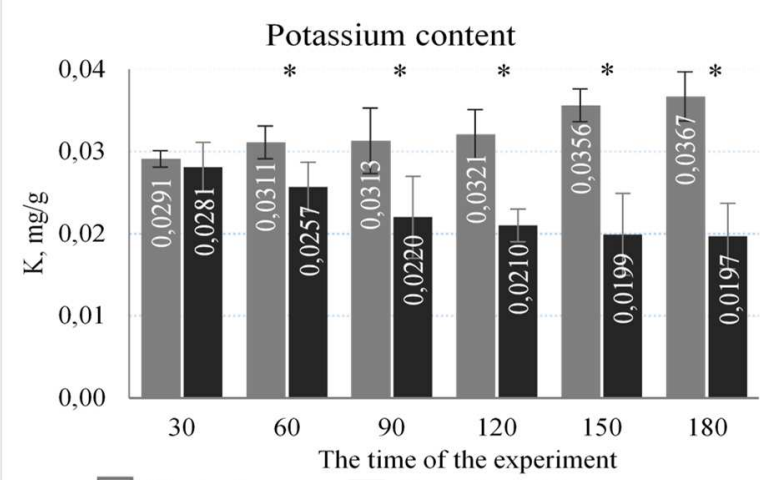

Control group $\square$ Experimental group

\section{d}

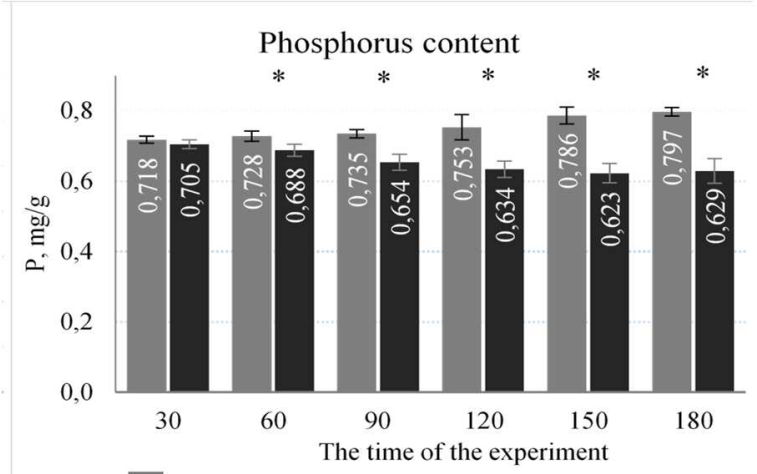

Control group $\square$ Experimental group

$\mathrm{b}$

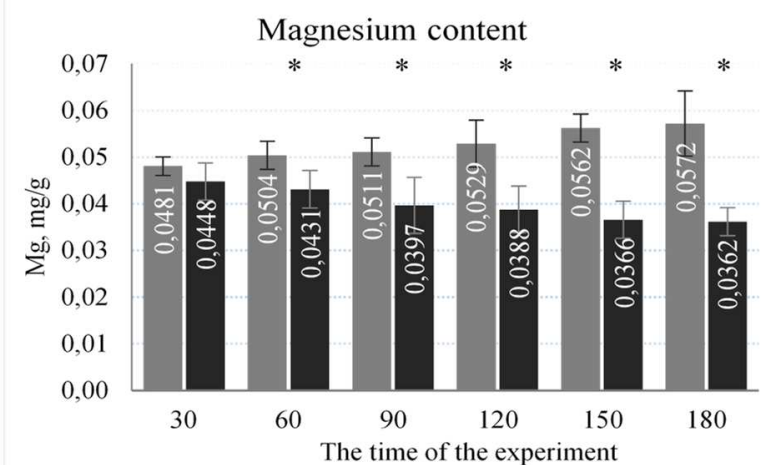

Control group $\square$ Experimental group

Fig. 4. The main indexs of the macronutrient composition of the humerus of rats in the dynamics of the experiment Note: all settings when paired comparison of control and experimental subgroups $(p<0.05)$ 
Similar trends were recorded for the content of P, Mg, and K (fig. 3b, c, d). However, the mean values of $\mathrm{P}, \mathrm{Mg}$ and $\mathrm{K}$ in the femurs of the animals of the experimental group were significantly lower than those of the animals of the control group on 60 and 180 days of observation.

Changes in the macronutrient composition of the humerus in experimental animals were similar to those described for the femurs. From 30 days until the end of the experiment, the mean Ca content in the humerus of animals of the experimental group decreased by $41.5 \%$ (fig. 4a). At 180 days of the experiment, the difference in the mean Ca content in the animals of the experimental and control groups was $62.4 \%$ $(1.17 \pm 0.24 \mu \mathrm{g} / \mathrm{g}$ and $3.11 \pm 0.21 \mu \mathrm{g} / \mathrm{g}$, respectively, $\mathrm{p}<0.001)$.

Similar changes, but significant from the 60th day of the experiment, established for the content of P, Mg, K (fig. 4b, c, d). During 180 days of uncontrolled hyperglycemia in the humerus of animals of the experimental group there was a decrease in the content of $\mathrm{P}$ by $10.8 \%, \mathrm{Mg}-$ by $19.2 \%, \mathrm{~K}-$ by $29.9 \%$.

The experimental study was aimed at establishing changes in biomechanical parameters and concentrations of chemical elements in the long tubular bones of adult rats under conditions of chronic hyperglycemia. Data on the pathological effect of hyperglycemia on bones are confirmed by spectrophotometric and biomechanical results of the study. This is manifested in a decrease in the trivalent properties of bones and a significant loss of macronutrients such as $\mathrm{Ca}, \mathrm{P}, \mathrm{Mg}$, and $\mathrm{K}$.

Our results of changes in the biomechanical parameters of rat bones and data on significant loss of macronutrients in the tubular bones of rats, may indicate a decrease in bone mineral density and impaired metabolism, this is confirmed by several authors and complements information on the effects of hyperglycemia on the skeletal system in particular $[2,3]$.

The pathological changes described by us are consistent with the experimental data obtained by (Ohta $\mathrm{T}$ et al., Zhang J et al). As well as the results of clinical observations conducted by (Abdulrahman $\mathrm{N}$ et al). These authors note the loss of bone tissue, in particular in the composition of long tubular bones in conditions of chronic hyperglycemia, which leads to an increased risk of fractures $[1,10,15]$.

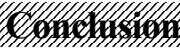

Thus, the results obtained by us indicate that in the long tubular bones of adult rats in conditions of chronic hyperglycemia there are gradually increasing changes in biomechanical properties, which deepen with each subsequent period of observation. They are accompanied by a decrease in bone strength against the background of significant losses of essential macronutrients. In general, during the experiment in the femurs of animals of the experimental group were significantly lower than in animals of the control group. The level of $\mathrm{Ca}$ on the 180th day of observation decreased by $61.8 \%, \mathrm{P}$ by $13.3 \%, \mathrm{Mg}-$ by 20.4 $\%, \mathrm{~K}-$ by $26.8 \%$ in the humerus: $\mathrm{Ca}-62.4 \%, \mathrm{P}-$ by $12.8 \%, \mathrm{Mg}-$ by $23.7 \%, \mathrm{~K}-$ by $29.9 \%$, thus forming the appropriate pathomorphological basis of diabetic osteopathy.

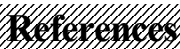

1. Abdulrahman N, McComb C, Foster JE. Deficits in trabecular bone microarchitecture in young women with type 1 diabetes mellitus. Journal of Bone and Mineral Research. 2015; 30(8): 1386-1393. Doi: 10.1002/jbmr.2465.

2. Bonora E, DeFronzo RA. Diabetes complications, comorbidities and related disorders. Cham: Springer Nature Switzerland. 2020; 724. Doi: 10.1007/978-3-030-36694-0.

3. Burr D, Allen M. Basic and Applied Bone Biology. Academic Press.2019; 2nd Edition: 454 s.

4. Carvalho FR, Calado SM, Silva GA, Diogo GS, Moreira da Silva J, Reis RL et al. Altered bone microarchitecture in a type 1 diabetes mouse model Ins2Akita. J Cell Physiol. 2019; 234 (6): 9338-9350. Doi: 10.1002/jcp.27617.

5. de Mello-Sampayo C, Agripino AA, Stilwell D, Vidal B, Fernando AL, Silva - Lima B et al. Chronic Hyperglycemia Modulates Rat Osteoporotic Cortical Bone Microarchitecture into Less Fragile Structures. Int. J Endocrinal.2017; 2017: 4603247. Doi: $10.1155 / 2017 / 4603247$.

6. de Oliveira GJPL, Basso TLD, Fontanari LA, Faloni APS, Júnior ÉM, Orrico SRP. Glycemic control protects against trabecular bone micro-architectural damage in a juvenile male rat model of streptozotocin-induced diabetes. Endocrine Research.2017; 42 (3). doi.org/10.1080/07435800.

7. Jiao H, Xiao E, Graves DT. Diabetes and Its Effect on Bone and Fracture Healing. Curr Osteoporosis Rep. $2015 ; 13$ (5): $327-$ 35. Doi: $10.1007 / \mathrm{s} 1191401502868$.

8. Joshi A, Varthakavi P, Chadha M, Bhagwat N. A study of bone mineral density and its determinants in type 1 diabetes mellitus. J Osteoporosis. 2013; 2013: 397-814. Doi: 10.1155/2013/397814.

9. Kanazawa I. Interaction between bone and glucose metabolism [Review]. Endocrinology J. 2017; Nov 29; 64 (11): $1043-1053$. Doi: 10.1507 / endocrj.EJ17-0323.

10. Ohta T, Kimura S, Hirata M, Yamada T, Sugiyama T. Bone morphological analyzes in Spontaneously Diabetic Torii (SDT) fatty rats. J. Vet. Med. Sci. 2015; 77 (10): 1330. doi: 10.1292/jvms.15-0154.

11. Rendina-Ruedy E, Graef JL, Davis MR, Hembree KD, Gimble JM, Clarke SL et al. Strain differences in the attenuation of bone accrual in a young growing mouse model of insulin resistance. J Bone Miner Metab. 2016; 34 (4): 380-94. Doi: 10.1007 / s007740150685z.

12. Schacter GI, Leslie WD. Diabetes and Bone Disease. Endocrinologist Metab Clin N Am. $2017 ; 46$ (1): $63-85$. Doi.org/10.1016/j.ecl.2016.09.010 
13. Shah VN, Carpenter RD, Ferguson VL, Schwartz AV. Bone health in type 1 diabetes. Curr Opin Endocrinology Diabetes Obes. 2018; 25 (4): 231-236. Doi: 10.1097/MED.0000000000000421.

14. Zhang J, Chen X, Chen B, Tong L, Zhang Y. Tetrahydroxy stilbene glucoside protected against diabetes-induced osteoporosis in mice with streptozotocin-induced hyperglycemia. Phytotherapy Research. 2018; 33.1-10. Doi: 10.1002 / ptr.6240.

15. Zhukouskaya VV, Eller-Vainicher C, Shepelkevich AP, Dydyshko Y, Cairoli E, Chiodini I. Bone health in type 1 diabetes: focus on evaluation and treatment in clinical practice. J Endocrinology Invest. 2015; 38 (9): 941-50. Doi: 10.1007/s40618-0150284-9.

Стаття надійшла 29.05.2020 p.

DOI 10.26724/2079-8334-2021-2-76-238-242

UDC 612.0612.561:603.323.4

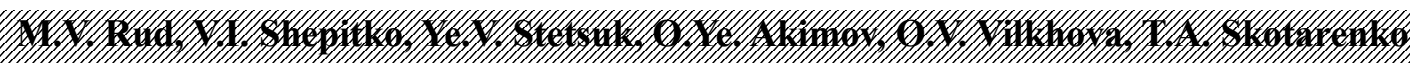

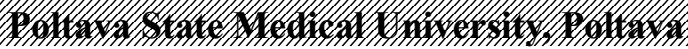

\section{THE REACTION OF IMMUNOCOMPETENT LIVER CELLS DURING CHEMICAL CASTRATION OF MALE RATS CAUSED BY THE INTRODUCTION OF TRIPTORELIN ACETATE}

e-mail: rudmariia@gmail.com

The purpose of our study was to elucidate the qualitative and quantitative changes in immunocompetent liver cells during chemical castration of male rats of central origin caused by the introduction of triptorelin acetate solution at different time intervals, to determine the sources of nitric oxide production as well as the effects of quercetin on morphological and quantitative changes of antigenpresenting liver cells. The morphological changes in the experimental groups with central testosterone deprivation and with its subsequent correction with quercetin on the 30th day of the experiment are identical and include signs of stromal - vascular changes in the form of an increase in the thickness of the beam system and minor venous stasis with macrophage infiltration. Central 30 - day deprivation of testosterone synthesis leads to a shift in the functioning of enzymes of the nitric oxide cycle in rat liver towards a predominance of the activity of inducible NO-synthase.

Key words: liver, macrophage, deprivation of testosterone, triptorelin, nitric oxide, NO-synthase, quercetin, rats.

\section{М.В. Рудь, В.І. Шепітько, С.В. Стецук, О.Є. Акімов, О.В. Вільхова, Т.А. Скотаренко РЕАКЦІЯ ІМУНОКОМПЕТЕНТНИХ КЛІТИН ПЕЧІНКИ ПРИ ХІМІЧНІЙ КАСТРАЦЇ САМЦІВ ЩУРІВ, ВИКЛИКАНІЙ ВВЕДЕННЯМ ТРИПТОРЕЛІНУ АЦЕТАТУ}

Метою дослідження було з'ясувати якісні та кількісні зміни імунокомпетентних клітин печінки під час хімічної кастрації самців щурів центрального походження, спричинених введенням розчину триптореліну ацетату через різні проміжки часу, визначити джерела вироблення оксиду азоту, а також вплив кверцетину на морфологічні та кількісні зміни антигенпрезентуючих клітин печінки. Морфологічні зміни в експериментальних групах 3 центральною депривацією тестостерону та 3 подальшою його корекцією кверцетином на 30 день експерименту ідентичні і включають ознаки стромально-судинних змін у вигляді збільшення товщини балкової системи та незначний венозний застій 3 макрофагальною інфільтрацією. Центральна 30-денна депривація синтезу тестостерону призводить до зсуву функціонування ферментів циклу оксиду азоту в печінці щурів у бік переважання активності індуцибельної NO-синтази.

Ключові слова: печінка, макрофаг, депривація тестостерону, трипторелін, оксид азоту, NO-синтаза, кверцетин, щури.

The study is a fragment of the research project "Experimental morphological study of cryopreserved placenta transplants action of diphereline, ethanol and $1 \%$ methacrylic acid on the morphofunctional status in a number of internal organs", state registration No. 0119 U102925.

Testosterone is an important biological regulator of metabolic processes in the male body. However, with age, the intensity of testosterone production decreases, which leads to its deficiency in the body with further development of anxiety and depressive behaviour, which is associated with apoptosis of hippocampal neurons as a result of the oxidative stress development [10]. In our previous studies, it was shown that central deprivation of testosterone synthesis by triptorelin leads to overproduction of nitric oxide and the development of oxidative stress in the testes of rats [11].

Testosterone deficiency can affect not only the testes and neurons, but also other organs and tissues of the body, in particular the liver. So, with insufficient testosterone production and protein deficiency, fat accumulates in hepatocytes, which is eliminated by an increase in testosterone levels in the body [12]. Exogenous long - term administration of testosterone improves the course of non-alcoholic fatty liver disease by reducing the intensity of fatty liver infiltration [14].

The liver, due to its structure, anatomical location and performance of specific functions plays an important role in the processes of interaction of the organism with the environments. Because the liver is a major barrier to the entry of nutrients, xenobiotics, and microorganisms from the gut into the bloodstream, 